\title{
Occurrence of Sclerotinia sclerotiorum in Soybean Fields in East-Central Illinois and Enumeration of Inocula in Soybean Seed Lots
}

\author{
G. L. Hartman, USDA, Agricultural Research Service, and Department of Crop Sciences, and L. Kull and Y. H. \\ Huang, Department of Crop Sciences, 70 EASB, 1101 W. Peabody, University of Illinois at Urbana-Champaign, \\ Urbana 61801-4723
}

\begin{abstract}
Hartman, G. L., Kull, L., and Huang, Y. H. 1998. Occurrence of Sclerotinia sclerotiorum in soybean fields in east-central Illinois and enumeration of inocula in soybean seed lots. Plant Dis. 82:560-564.

Sclerotinia stem rot (SSR) of soybean is an important disease in the northern soybean-production areas of the United States. In Illinois, the occurrence of SSR has been limited to the northern-most soybean-production areas. In this study, soybean fields in east-central Illinois were surveyed for incidence of SSR. Of 68 fields surveyed, 31 contained SSR. Of the fields with SSR, 25 had between 1 and 5\% SSR incidence, while 6 fields had more than 5\% SSR incidence. The pattern of the disease in one field was mapped, and the spatial distribution of SSR was aggregated with a Lloyd's index of 1.4. In addition to field incidence of SSR, seed lots suspected of being contaminated with Sclerotinia sclerotiorum sclerotia were obtained from the Illinois Crop Improvement Association. Sclerotia and seeds were separated, and seeds were germinated to determine the level of seedborne infection by S. sclerotiorum. Sclerotia were recovered from 71 of 81 seed lots. Most of the seed lots were from the north-central area of Illinois, but one seed lot was from Madison County in the southwestern area of the state, and three and six seed lots contaminated with sclerotia were from Iowa and Wisconsin, respectively. Sclerotia counts ranged from 0 to 363 per seed lot. Normal-appearing seeds from the 81 seed lots (100 to 200 seeds per lot) were tested for germination and incidence of seedborne infection by $S$. sclerotiorum. Eight seed lots had at least one infected seed, and the incidence of seed infection ranged from 0.07 to $0.1 \%$. From 10 randomly selected seed lots of the 81 , discolored, shriveled seeds were selected and germinated to determine the incidence of seedborne infection. Seed infection rates ranged from 0 to $70 \%$. The occurrence of SSR throughout Illinois and the importance of seedborne infection as a source of inoculum dispersal need further documentation.
\end{abstract}

Additional keywords: epidemic, white mold

Sclerotinia sclerotiorum has a broad host range $(6,7)$ that includes high-value crops, such as alfalfa, bean, cabbage, canola, lettuce, peanut, soybean, sugar beet, sunflower, tobacco, and tomato. On soybean plants, the disease is referred to as Sclerotinia stem rot (SSR) (7). SSR is one of the most important soybean diseases in Illinois, Iowa, Michigan, Minnesota, North Dakota, Ohio, and Wisconsin and occurs in southern Ontario and several countries in South America $(3,7,17)$. Although the pathogen is widespread geographically, SSR has been limited to the northern soybean-production

Corresponding author: G. L. Hartman E-mail: ghartman@uiuc.edu

Mention of a trademark or proprietary product does not constitute a guarantee or warranty of the product by the U.S. Department of Agriculture and does not imply its approval to the exclusion of other products that may also be suitable.

Accepted for publication 2 February 1998.

Publication no. D-1998-0312-01R

(C) 1998 The American Phytopathological Society area of the United States; however, SSR on soybean was ranked second in yield-reducing diseases in the United States in 1994 (17).

In Illinois, SSR was first reported on soybean in the northern area of the state in 1946 (4). In soybean disease-monitoring plots at 18 locations in Illinois from 1977 to 1987 and in 1990 and 1991, SSR was not ranked among the 12 most important soybean diseases found (5). Although the disease has occurred for a number of years in northern Illinois, information about its distribution and importance in Illinois is lacking. In 1996, several soybean growers from eastern Illinois contacted plant pathologists at the University of Illinois, UrbanaChampaign, about the occurrence of SSR in their fields. An initial visit with the growers indicated that the disease had occurred for several years in at least one field and was thought to be widespread.

S. sclerotiorum is seedborne in soybean $(12,13,16)$. In addition to being seedborne, sclerotia often are mixed with seeds during harvest. If a soybean crop is harvested as a seed crop for the next year, the seeds are cleaned so light-weight seeds, sclerotia, and other contaminants are reduced, although not all sclerotia and infected seeds may be eliminated. Harvested seeds sold for processing usually are taken to the elevator without being cleaned and may contain sclerotia and infected seeds. Seed-certification requirements do not exist in the United States for soybean seeds infected or seed lots infested with $S$. sclerotiorum.

The objectives of this report were to (i) survey the occurrence of SSR in soybean fields, primarily in Iroquois County in eastcentral Illinois; (ii) determine the spatial distribution of SSR incidence in a soybean field with high disease incidence; and (iii) record the incidence of sclerotia and infected seed in soybean seed lots from fields, primarily in central and northern Illinois.

\section{MATERIALS AND METHODS}

Survey area and SSR assessment. The survey area in east-central Illinois was in Iroquois County, between 40.5 and $41^{\circ} \mathrm{N}$ latitude and 87.4 and $87.9^{\circ} \mathrm{W}$ longitude (Fig. 1). There were 62 fields in 12 townships sampled in Iroquois County, and 6 fields sampled in Indiana. Most fields centered around six townships near Watseka, IL. A grid, $\approx 3$ to $5 \mathrm{~km}^{2}$, overlaid the survey area and provided the approximate distribution of the 68 randomly chosen fields, which were each 3 to $5 \mathrm{~km}$ apart. There was no prior knowledge of SSR in any of the fields surveyed.

Within each field, two V-shaped patterns were walked, and three stops, $\approx 300 \mathrm{~m}$ apart, were selected per pattern (six sampling sites per field). Incidence of SSR was determined by counting the number of plants infected per 100 consecutive plants in a row per sample site. Sampling dates were 1 through 4 October 1996, and the maturity of soybean plants during this period ranged from early to harvest maturity. Row spacing and field location within a section were recorded. A $t$ test was used to determine whether SSR incidence was different in fields with a row spacing of $<76 \mathrm{~cm}$ compared to row spacings of $\geq 76 \mathrm{~cm}$.

Within-field distribution of SSR. In one field, a grid pattern was established in a $100 \times 133 \mathrm{~m}$ area that contained 25 planted rows (76- $\mathrm{cm}$ row spacing) and $50 \mathrm{~m}$ between 24 sampling sites within a row. SSR was evaluated at a total of 192 sampling sites by counting the number of plants with SSR per 100 plants along a single row. The sampling date was 7 October 1996, and the 
plants were at harvest maturity. Distribution data were analyzed by the Lloyd's index of patchiness (10). The degree of SSR distribution was based on: $r=\left\{\mu+\left[\left(\sigma^{2} / \mu\right)-\right.\right.$ $1]\} / \mu$, where $\mu=$ mean incidence of SSR and $\sigma^{2}=$ variance. Spatial randomness, regularity, or aggregation was indicated by a value of $r<1,=1$, or $>1$, respectively. The spatial distribution was mapped by the following five groups of SSR incidence: $<11 \%, 11$ to $32 \%, 33$ to $54 \%, 55$ to $76 \%$, and $>76 \%$.

Seed assays. The Illinois Crop Improvement Association, Champaign, provided seed samples from 81 seed lots from 1996 that were believed to be contaminated with sclerotia. These seed lots originated from soybean seed-production fields primarily located in central and northern Illinois; additionally, there were several seed lots from unknown counties in Iowa and Wisconsin. For each seed lot, the total number of seeds and sclerotia were separated and counted (broken sclerotia were counted as individuals), and for each lot, 100 or 200 seeds that appeared healthy were placed on dampened seed germination pads and incubated in a humid seed-germination chamber maintained at $17^{\circ} \mathrm{C}$. After 7 days, seeds with characteristic masses of white mycelia were transferred to acidified potato dextrose agar plates and incubated at $20^{\circ} \mathrm{C}$.

The appearance of 0.5- to 2-cm-diameter sclerotia, usually within 7 to 10 days, confirmed the presence of seedborne mycelia of $S$. sclerotiorum. Of the 81 seed lots, 10 seed lots were randomly selected, and only discolored-shriveled seeds were placed in a humid seed-germination chamber (as described above) to evaluate their germination and the occurrence of seedborne S. sclerotiorum. Of the 10 seed lots, 4 were from Champaign County (17, 20, 5, and 23 seeds in each), 3 were from LaSalle County $(4,8$, and 5 seeds in each), and 1 each was from Cumberland County (13 seeds), Logan County (15 seeds), and McClean County (9 seeds).

\section{RESULTS}

SSR survey. Of 68 fields surveyed, 31 had SSR present (Fig. 1). Of the fields with SSR, only six fields had a disease incidence of $>5 \%$. The occurrence of SSR was greatest in Belmont and Sheldon townships, which had greater numbers of fields and plants within a field with SSR (Table 1). Of the 68 fields surveyed, 22 fields had row spacings $\geq 76 \mathrm{~cm}$, with $36 \%$ SSR incidence; 46 fields had row spacings $<76 \mathrm{~cm}$, with $48 \%$ SSR incidence. There was no significant $(P=0.05)$ difference in the percentage of SSR incidence between the two row-spacing groups.

Data supported an aggregated spatial distribution of SSR incidence (Fig. 2). The mean SSR incidence and the variance based on 192 sampling sites were $33 \%$ and 484 , respectively, with a Lloyd's index of 1.4. In the five SSR incidence classes, there was one sampling site that had no SSR incidence, 36 sampling sites that had $<11 \%$ SSR incidence, 69 sampling sites that had between 11 and 32\% SSR incidence, 49 sampling sites that had between 33 and 54\% SSR incidence, 31 sampling sites that had between 55 and $76 \%$ SSR incidence, and 7 sampling sites that had $>76 \%$ SSR incidence.
Seed assays. Most of the seed lots were from the north-central area of Illinois (Fig. $3)$. Sclerotia were recovered from 71 of the 81 seed lots suspected of having S. sclerotiorum present, with sclerotia per seed lots ranging from 0 to 363 (Table 2). The number of seed lots with infected seeds was eight. Seed germination rates were all more than $93 \%$, except for one lot from

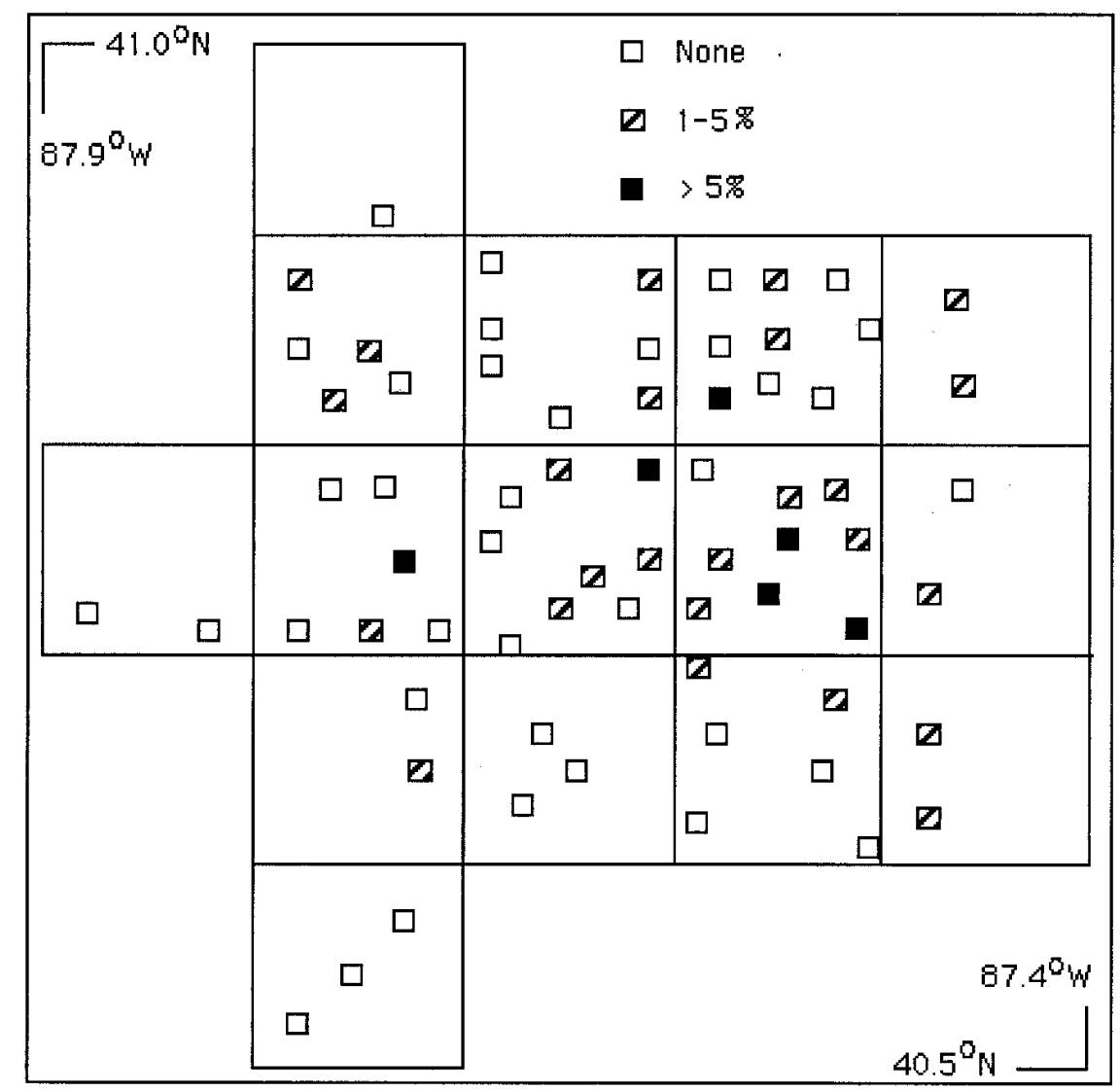

Fig. 1. Distribution and percentage of Sclerotinia stem rot of soybean based on 600 plant samples from each of 68 fields, representing 62 fields in 12 townships in Iroquois County, IL, and 6 fields in Indiana in 1996.

Table 1. Number of soybean fields sampled, percent fields with Sclerotinia stem rot (SSR), mean incidence level of SSR, and mean percentage of six sites within each field with SSR in 11 townships in Iroquois County, IL, and six adjacent fields in Indiana

\begin{tabular}{|c|c|c|c|c|}
\hline Township & $\begin{array}{c}\text { No. of fields } \\
\text { sampled }\end{array}$ & $\begin{array}{c}\text { Fields with } \\
\text { SSR }(\%)\end{array}$ & $\begin{array}{l}\text { Mean SSR } \\
\text { incidence }^{\mathrm{a}}\end{array}$ & $\begin{array}{c}\text { Mean sites } \\
\text { within each field } \\
\text { with SSR }(\%)^{\mathbf{b}}\end{array}$ \\
\hline Ash Grove & 2 & 50 & 1.7 & 17 \\
\hline Belmont & 9 & 56 & 8.1 & 57 \\
\hline Concord & 9 & 33 & 2.8 & 45 \\
\hline Crescent & 6 & 33 & 2.8 & 59 \\
\hline Fountain Creek & 3 & 0 & 0 & 0 \\
\hline Iroquois & 6 & 50 & 2.1 & 39 \\
\hline Middleport & 7 & 29 & 2.4 & 42 \\
\hline Milford & 3 & 0 & 0 & 0 \\
\hline Onarga & 2 & 0 & 0 & 0 \\
\hline Sheldon & 9 & 89 & 5.5 & 41 \\
\hline Stockland & 6 & 33 & 1.5 & 42 \\
\hline Indiana $^{c}$ & 6 & 83 & 1.3 & 23 \\
\hline Mean & & 46 & 2.3 & 30 \\
\hline
\end{tabular}

${ }^{a}$ Mean incidence of SSR, based on 600 plants per field.

${ }^{b}$ Mean percentage of SSR of six sites per field that were positive for SSR incidence.

${ }^{c}$ Six fields in Indiana adjacent to Iroquois County, IL. 
Ogle County, in which seed germination was $75 \%$. From 10 of the 81 seed lots in which discolored, shriveled seeds were selected, 2 of the seed lots from Champaign County had 6 and 70\% seed infection, 1 seed lot from LaSalle County had 50\% seed infection, and 1 seed lot from McClean County had $11 \%$ seed infection. No infected seeds were found from Cumberland and Logan Counties.

\section{DISCUSSION}

In 1996, there was evidence of an epidemic of SSR on soybeans in east-central Illinois. We do not know of any other reports of an SSR epidemic of this proportion on soybean this far south in the United States. Even in Iroquois County, IL, there had not been any previously published report on the occurrence of SSR. The field that we intensively sampled to determine the spatial distribution of SSR had been in a rotation of corn-soybean for the previous 2 years and was in continuous corn for 10 years prior to the 2-year cornsoybean rotation. The source of inocula for the epidemic in this field is unknown, but the grower did mention that the field was heavily infested with weeds and had been planted to corn for 10 years to reduce the weed pressure. Alternative weed hosts were implicated as an inoculum source for SSR of snap bean in New York (1). The history of weed pressure in the field that we intensively sampled may have contributed to the maintenance of the sclerotia population that produced such an epidemic in a susceptible soybean crop in 1996.

First reports of disease epidemics in new geographic areas suggest that changes may have occurred in pathogen density and range, weather conditions, and crop management practices. For example, in Oregon, S. sclerotiorum devastated the pear crop in 1993 due to unusually wet and cool conditions (14). In Iroquois County, IL, the weather conditions during the period from July through August 1996, were ideal for an SSR epidemic: there were 12 rain days in July and 13 fog days in August (9).

Cultural practices that enhance soil moisture, lower canopy temperature, and reduce air movement are known to increase SSR (15). Based on our survey, there was a trend for higher SSR incidence in narrower rows than in wider rows, which concurs with a report that found more SSR in row spacings of 25 to $38 \mathrm{~cm}$ compared to $76-$ $\mathrm{cm}$ row spacing (8). Spread of the pathogen to new fields may occur through aerial
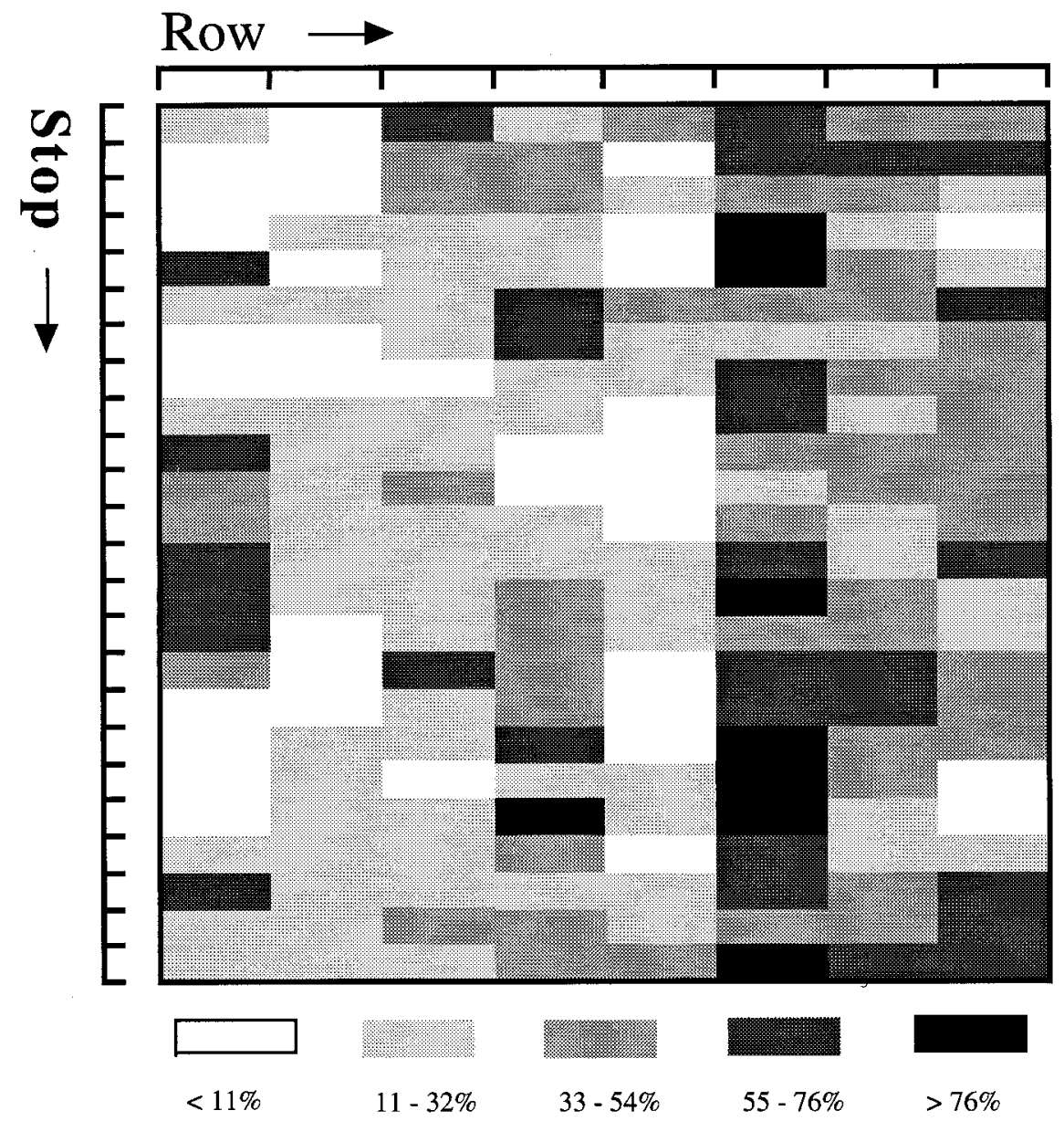

Fig. 2. Spatial distribution of Sclerotinia stem rot of soybean in a grid pattern from a sampled area of $100 \times 133 \mathrm{~m}$ from one field in Iroquois County, IL, in 1996. Within each of eight columns (every 25 plant rows at $76 \mathrm{~cm}$ row spacing), there were 24 sampling sites $50 \mathrm{~m}$ apart. At each sampling site, 100 plants were counted, and the incidence of Sclerotinia stem rot was recorded. distribution of ascospores during the season, movement of sclerotia by mechanical means, including farm machinery and flooding, or infected seeds or infested seed lots.

SSR in Illinois was not reported in disease-monitoring plots that recorded 12 soybean diseases at multiple locations throughout the state from 1977 to 1987 and in 1990 and 1991 (5). Although S. sclerotiorum does not occur in all soybean-production areas, the pathogen on host crops, such as dry bean, has occurred in all major production areas in the United States (15). $S$. sclerotiorum has the potential to become more widespread in the major soybeanproduction areas, as indicated by its increased southward occurrence in Illinois.

The distribution of the disease within the one field we intensively sampled was spatially aggregated, suggesting disease incidence is determined primarily by how the inoculum is produced and deposited within that field (2). In many of the fields we surveyed, only small pockets of plants with SSR were observed, indicating that perhaps sclerotia and, hence, apothecia were localized to the specific area where disease occurred. It is unknown whether the source of sclerotia resulted from a seed-associated deposit or from other sources, such as windblown ascospores. Sclerotia of S. sclero-

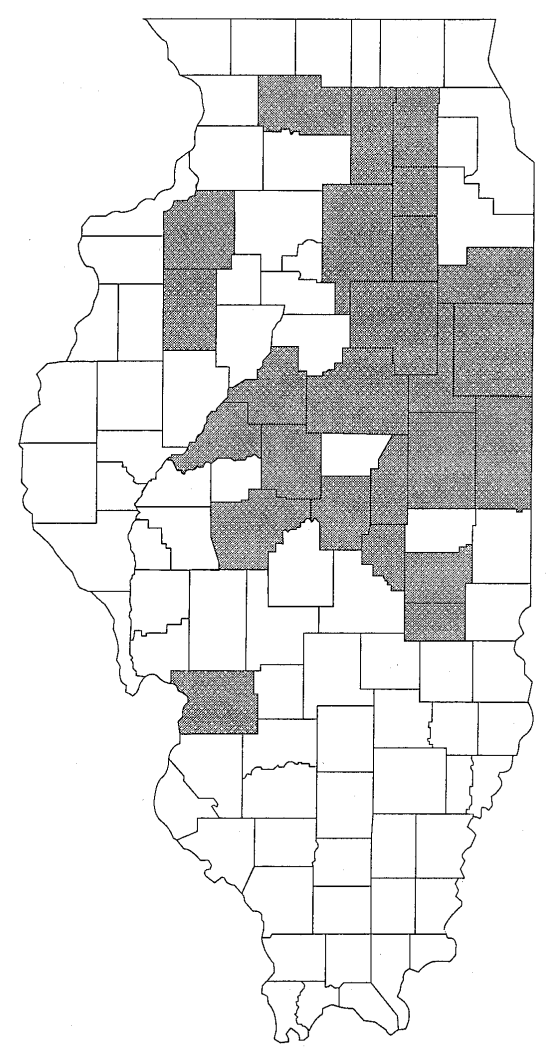

Fig. 3. Occurrence of Sclerotinia stem rot of soybean in Illinois based on 81 seed lots supplied by the Illinois Crop Improvement Association. Shaded counties in the state represent the origin of seed lots that were positive for sclerotial contamination by Sclerotinia sclerotiorum. 
tiorum can remain viable for many years in the soil $(3,7,11,15)$, and because they produce apothecia that result in numerous ascospores, a susceptible soybean crop growing in infested soil will most likely become infected under environmental conditions conducive for disease development. Various sizes of sclerotia also can be harvested with seed, remain viable in seed lots, and be planted with seed in the spring, resulting in potential primary inocula for that season. Although the distribution pattern in the field we intensively sampled suggests that the inoculum was produced within this field, our study does not eliminate the possibility of sclerotia-infested seed lots or infected seeds as the original source of inocula.

Because the pathogen is seedborne (12, $13,16)$, the potential spread of the pathogen by infected seeds and infested seed lots may cause a proliferation of SSR into uninfested regions. Infected soybean seeds and sclerotia-contaminated seed lots may be the primary source of inocula in new fields. For infected seeds to become an inoculum source, soil conditions must allow continued growth of mycelia to colonize the seed and seedlings and produce sclerotia, apothecia, and ascospores that germinate on senescing flower petals during that same growing season. It is unknown whether infected seeds can be the source of inocula for a field with no SSR; however, based on our observations, infected seeds in a seed germinator were colonized with mycelia that produced sclerotia within 7 days. Studies need to be conducted to determine whether appropriate certification requirements need to be established for the soybean seed industry. Seed cleaners may be effective in separating most sclerotia and infected, shriveled, and light-weight seeds, but the efficiency among seed cleaners used by the seed industry may vary. If infected or infested seeds or sclerotia-contaminated seed lots play a role in the spread of the fungus to new fields, then SSR certification requirements may be needed. The increasing occurrence of SSR also may necessitate standardization of seed-cleaning and improved detection systems of S. sclerotiorum in seed lots.

Further surveys within Illinois and the north-central region of the United States are needed to provide more information as to how widespread SSR is on soybeans. The original source of the inoculum in Iroquois County is unknown, but incidence patterns suggest that it may have initiated in one of two townships that now have the highest incidence of SSR. Although other means of pathogen movement, such as airborne ascospores and mechanical movement of sclerotia, should not be overlooked, the importance of sclerotia and infected seed in seed lots needs to be investigated further to determine their role in the spread of the pathogen. Also, standardization in seed certification and seedcleaning equipment may be needed to reduce the risk of providing primary inoculum in uninfested fields. Ultimately, the detection and elimination of $S$. sclerotiorum in bean seed production fields may help reduce the spread of this pathogen to new areas.

\section{ACKNOWLEDGMENTS}

We thank R. Warsaw for assisting in collecting survey data on the incidence of Sclerotinia stem rot and G. Cook of the Illinois Crop Improvement Association, for providing soybean seed lots.

\section{LITERATURE CITED}

1. Abawi, G. S., and Grogan, R. G. 1975. Source of primary inoculum and effects of temperature and moisture on infection of beans by Whetzelinia sclerotiorum. Phytopathology 65: 300-309.

2. Boland, G. J., and Hall, R. 1988. Relationships between the spatial pattern and number of apothecia of Sclerotinia sclerotiorum and stem rot of soybean. Plant Pathol. 37:329336.

3. Boland, G. J., and Hall, R. 1988. Epidemiology of Sclerotinia stem rot of soybean in Ontario. Phytopathology 78:1241-1245.

4. Chamberlain, D. W. 1951. Sclerotinia stem rot of soybeans. Plant Dis. Rep. 35:490-491.

5. Eathington, S. R., Lim, S. M., Nickell, C. D., and Pataky, J. K. 1993. Disease pressure in Illinois. Plant Dis. 77:1136-1139.

6. Farr, D. F., Bills, G. F., Chamoris, G. P., and Rossman, A. Y. 1989. Fungi on Plants and Plant Products in the United States. The American Phytopathological Society, St. Paul, $\mathrm{MN}$

7. Grau, C. R. 1988. Sclerotinia stem rot of soybean. Pages 56-66 in: Soybean Diseases of the North Central Region. T. D. Wyllie and D. H. Scott, ed. The American Phytopathological Society, St. Paul, MN.

8. Grau, C. R., and Radke, V. L. 1984. Effect of cultivars and cultural practices on Sclerotinia stem rot of soybean. Plant Dis. 68:56-58.

9. Hoffman, D. D., Hartman, G. L., Mueller, D. S., Leitz, R. A., Nickell, C. D., and Pedersen, W. L. Yield response of soybean cultivars infected with Sclerotinia sclerotiorum. Plant Dis. In press.

10. Lloyd, M. 1967. Mean crowding. J. Animal Ecol. 36:1-30.

Table 2. Number of soybean seed lots assayed and number infested with Sclerotinia sclerotiorum sclerotia, number of seed lots with seedborne S. sclerotiorum, mean number of seeds per seed lot, mean and range of sclerotia per seed lot, percent seed germination, and mean percentage of seeds infected with S. sclerotiorum

\begin{tabular}{|c|c|c|c|c|c|c|c|}
\hline $\begin{array}{l}\text { Illinois county } \\
\text { or state }\end{array}$ & $\begin{array}{c}\text { No. of } \\
\text { seed lots }\end{array}$ & $\begin{array}{l}\text { No. of seed } \\
\text { lots with } \\
\text { sclerotia }\end{array}$ & $\begin{array}{c}\text { No. of seed } \\
\text { lots with } \\
\text { infected seed }\end{array}$ & $\begin{array}{l}\text { Mean no. of } \\
\text { seeds per } \\
\text { seed lot }\end{array}$ & $\begin{array}{c}\text { Mean no. and } \\
\text { range of sclerotia } \\
\text { per seed } \text { lot }^{\mathrm{a}}\end{array}$ & $\begin{array}{l}\text { Seed germination } \\
(\%)^{\mathrm{b}}\end{array}$ & $\begin{array}{c}\text { Infected seed } \\
(\%)^{\mathbf{b}, c}\end{array}$ \\
\hline Adams & 1 & 1 & 0 & 895 & 1 & 97 & 0 \\
\hline Champaign & 4 & 3 & 1 & 385 & $5(2-14)$ & 97 & 0.1 \\
\hline Cumberland & 1 & 1 & 0 & 164 & 4 & 93 & 0 \\
\hline Ford & 31 & 27 & 2 & 493 & $28(0-363)$ & 98 & 0.07 \\
\hline Grundy & 1 & 1 & 1 & 320 & 10 & 98 & 1 \\
\hline Henry & 1 & 1 & 0 & 1,031 & 3 & 100 & 0 \\
\hline Iroquois & 3 & 3 & 0 & 694 & $47(6-121)$ & 100 & 0 \\
\hline Kane & 6 & 2 & 3 & 657 & $3(1-5)$ & 98 & 0.4 \\
\hline Kankakee & 2 & 2 & 0 & 379 & $65(4-125)$ & 99 & 0 \\
\hline Knox & 3 & 3 & 0 & 808 & $3(3-4)$ & 99 & 0 \\
\hline Lasalle & 3 & 3 & 0 & 292 & $46(3-122)$ & 99 & 0 \\
\hline Lee & 1 & 1 & 0 & 444 & 6 & 95 & 0 \\
\hline Logan & 1 & 1 & 0 & 471 & 8 & 99 & 0 \\
\hline Macon & 1 & 1 & 0 & 370 & 3 & 98 & 0 \\
\hline Madison & 1 & 1 & 0 & 836 & 3 & 99 & 0 \\
\hline McClean & 1 & 1 & 0 & 491 & 2 & 99 & 0 \\
\hline Ogle & 2 & 2 & 0 & 633 & 1 & 75 & 0 \\
\hline Piatt & 1 & 1 & 0 & 833 & 2 & 95 & 0 \\
\hline Sangamon & 1 & 1 & 0 & 1,286 & 1 & 100 & 0 \\
\hline Tazewell & 4 & 3 & 0 & 693 & $2(0-5)$ & 94 & 0 \\
\hline Vermilion & 3 & 3 & 0 & 1,264 & $11(4-24)$ & 99 & 0 \\
\hline Iowa & 3 & 3 & 1 & 630 & $3(2-3)$ & 100 & 0.3 \\
\hline Wisconsin & 6 & 6 & 0 & 507 & $3(1-6)$ & 99 & 0 \\
\hline
\end{tabular}

a Ranges of numbers of sclerotia are in parentheses.

b Seedborne infection and germination based on 100 or 200 normal-appearing seeds per seed lot.

${ }^{\mathrm{c}}$ Percent infected seeds $=$ (number of seeds from which $S$. sclerotiorum was recovered/total number of seeds assayed per county $) \cdot 100$. 
11. Merriman, P. R. 1976. Survival of sclerotia of Sclerotinia sclerotiorum in soil. Soil Biol. Biochem. 8:385-389.

12. Mueller, D. S., Hoffman, D. D., Nickell, C. D., Hartman, G. L., and Pedersen, W. L. 1997. Potential seed transmission of white mold on soybeans. (Abstr.) Phytopathology 87 (Suppl.): S68.

13. Nicholson, J. F., Dhingra, O. D., and Sinclair, J. B. 1972. Internal seed-borne nature of Scler- otinia sclerotiorum and Phomopsis sp. and their effects on soybean seed quality. Phytopathology 62:1261-1263.

14. Spotts, R. A., and Cervantes, L. A. 1996. Sclerotinia rot of pears in Oregon. Plant Dis. 80: 1262-1264.

15. Steadman, J. R. 1983. White mold-A serious yield-limiting disease of bean. Plant Dis. 76: 346-350.

16. Stovold, G. E., and Priest, M. J. 1986. A note on the incidence of internally-borne Sclerotinia sclerotiorum in soybean seed harvested in New South Wales. Aust. Plant Pathol. 15: 83-84.

17. Wrather, J. A., Anderson, T. R., Arsyad, D. M., Gai, J., Ploper, L. D., Porta-Puglia, A., Ram, H. H., and Yorinori, J. T. 1997. Soybean disease loss estimates for the top 10 soybean producing countries in 1994. Plant Dis. 81:107110. 